\title{
Consumption of game and pest species by small- and medium-sized carnivores
}

\section{Koen Van Den Berge ${ }^{\oplus 1, *}$, Sanne Van Den Berge ${ }^{\circledR 2}$, Timo Van der Veken ${ }^{1}$, Jan Gouwy $^{\oplus 1}$, Pieter Verschelde ${ }^{\oplus 3}$, Maxime Eeraerts ${ }^{\oplus 1, *}$}

${ }^{1}$ Department of Fauna and Exotics Management, Research Institute of Forest and Nature,

Gaverstraat 4, 9500 Geraardsbergen, Belgium.

${ }^{2}$ Forest \& Nature Lab, Department of Environment, Ghent University, Geraardsbergsesteenweg 267, 9090 Melle-Gontrode, Belgium.

${ }^{3}$ Department of Biometry, Methodology and Quality Assurance, Research Institute of Forest and

Nature, Gaverstraat 4, 9500 Geraardsbergen, Belgium.

*Corresponding authors: koen.vandenberge@inbo.be, maxime.eeraerts@gmail.com

\begin{abstract}
Ecosystem services are the contributions that natural ecosystems make to people. Mammalian carnivores can provide both positive and negative ecosystem services by consuming pest or game species, respectively. In this study, we determined the consumption of certain game and pest species for a guild of sympatric small- and medium-sized carnivores (European badger, red fox, European polecat, stone marten, stoat and least weasel). We found that game and pest species comprise a notable proportion of the diet, ranging from $0.0 \%$ to $12.6 \%$ and from $2.7 \%$ to $46.3 \%$, respectively. Furthermore, for all carnivores we found that the proportion of pest species such as rats and voles (i.e., positive ecosystem service) was higher than the proportion of game species such as pheasants, partridges and hares, i.e., negative ecosystem service). Moreover, stoat and weasel did not consume any game species. This study gives a first overview of the potential ecosystem services through consumption of pest and game species provided by small- and medium-sized carnivores.
\end{abstract}

Keywords. Dietary ecology, Mustelidae, red fox, ecosystem services, game consumption.

Van Den Berge K., Van Den Berge S., Van der Veken T., Gouwy J., Verschelde P., Eeraerts M. (2022). Consumption of game and pest species by small- and medium-sized carnivores. Belgian Journal of Zoology 152: 33-43. https://doi.org/10.26496/bjz.2022.97

\section{Introduction}

Biological diversity has invaluable intrinsic value, but is also functionally important, as it influences how ecological systems perform and deliver services to society (DíAz et al. 2018). This component of diversity that influences ecosystem dynamics and productivity is defined as 'functional biodiversity'. Functional biodiversity includes, e.g., pollination of crops by wild pollinators and crop pest control via natural enemies (LICHTENBERG et al. 2017; EERAERTS et al. 2019), both are typical examples of 'ecosystem services' (ES). Using the concept of ES is attractive because it helps us to describe how society is linked to nature and how it benefits from its services (HAINES-YOUNG \& POTSCHIN 2013). 
Within the ecosystem service context, hunting can be classified as a recreational ecosystem service or it can be classified as a production-based ecosystem service, depending on the local and national habits (SCHULP et al. 2014). Carnivorous species are often perceived as competitors in hunting game species (SILLERO-ZUBIRI \& LAURENSON 2001), or as a limiting factor with regard to the development of favourite game species populations (ROBERTSON \& ROSENBERG 1988). From a hunters' perspective, carnivores consuming game species (e.g., game birds and hares) are perceived as a negative ecosystem service - a so-called 'disservice'. On the other hand, the consumption of pest species such as rats and voles could be considered as positive ecosystem service near human settlements and in urban areas (LUND 2015) and for agriculture and horticulture (JACOB et al. 2014). As such, the perception of these negative and positive ecosystem services is clearly linked to and depends on the motivation or understanding of different stakeholders (see SWAN et al. 2020). Different stakeholders will most probably be unevenly represented in a human population, so that also the respective weight of the services can be appraised differently within a given society. Apart from these ES, carnivores can provide other (positive) ES, such as structuring the whole biological community and causing important changes in terrestrial trophic dynamics (TAMBLING et al. 2018) or regulating zoonotic disease reservoirs (OSTFELD \& HOLT 2004; KEUNE et al. 2013; HOFMEESTER et al. 2017).

Within the scope of this study, we focus on the predation on small game species (pheasant, partridge, hare) and on pest species (rats and voles) in Flanders. The grey partridge (Perdix perdix, hereafter named 'partridge') is native to but declining in Flanders (SCHEPPERS et al. 2019), in line with the trend everywhere in Western Europe (KUIJPER et al. 2009). However, its decline might have been masked for years in Flanders via private restocking initiatives. The common pheasant (Phasianus colchicus, hereafter called 'pheasant') is not native to Western Europe, but omnipresent in Flanders due to releases in the wild for hunting purposes during the sampling period. The European hare (Lepus europaeus, hereafter called 'hare') is native in the study area, however also in decline in Western Europe (SLIWINSKI et al. 2019). All three species can be hunted in Flanders during fall and winter, and their hunting rate is high. During the sampling period 14.387, 22.329 and 14.899 partridges were shot in 2002, 2010 and 2018, respectively, $96.233,100.946$ and 62.288 pheasants, and 39.860, 43.245 and 49.385 hares (INBO 2021).

Brown rats (Rattus norvegicus, hereafter called 'rat') are not native to Flanders and are among the most invasive mammals in Europe (CLOUT 2002). In general, rat populations flourish near human habitations (LUND 2015). In a very densely populated region as Flanders that is characterised by a small-scale, highly fragmented landscape with a dense road network (PISMAN et al. 2018), rat populations are expected to be high, certainly in the countryside where people keep poultry, have a waste pile and all kinds of barns, providing food and shelter in abundance. Voles (Myodes glareolus and Microtus spp.) on the other hand are native in Flanders and can occur in high numbers in agricultural landscapes, causing problems to horticultural crops (JACOB et al. 2014).

There is an increasing scientific interest in the intrinsic biodiversity value and functioning of carnivore species (e.g., PRUGH et al. 2009; ROEMER et al. 2009; RitchiE et al. 2012; TAMBLING et al. 2018). A common assumption is that carnivores can have a negative impact on game species populations or at least hamper the hunting harvest of these species (e.g., TAPPER et al. 1996; BRO et al. 2000; REYNOLDS et al. 2010), whereas it is expected that they have a top-down function in regulating pest populations (HANSKi et al. 2001; OSTFELD \& Holt 2004; TAMBLING et al. 2018; HoEKS et al. 2020; SWAN et al. 2020). Indeed, all small- and medium-sized carnivore species occurring in Flanders have a long history of being heavily persecuted by gamekeepers because of a negative reputation as mammalian predators, and their control has been practiced for decades to benefit small game populations and allow harvesting (REYNOLDS \& TAPPER 1996). However, empirical studies regarding the consumption of game and pest species by small- and medium-sized carnivores, are scarce (but see LANSZKI et al. 1999; LANSZKI \& 


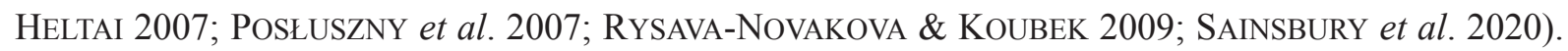
Hence, the objective of this study is to determine whether small- and medium-sized carnivores, among which red fox (Vulpes vulpes), European badger (Meles meles), stone marten (Martes foina), European polecat (Mustela putorius), stoat (M. erminea) and least weasel (M. nivalis), provide negative ecosystem services (i.e., the consumption of game birds and hares) or positive ecosystem services (i.e., the consumption of pest species such as rats and voles). We hypothesized the following:

1. We expect that some carnivores will consume more pest and game species than others. For example, red fox and stone marten, which are known as generalist predators (Ewer 1973; VAN DEN BERGE et al. 2021), are expected to consume more of the common species (both game and pest species) compared to more specialized carnivores such as weasel and polecat.

2. We expect that the carnivores in general will consume more pest than game species, as pest species (e.g., rats and voles) are more abundant compared to game species in Flanders.

\section{Material and methods}

\section{Study area and data collection}

The study was conducted in Flanders $\left(13,682 \mathrm{~km}^{2}\right)$, the northern part of Belgium. The dominant land use types are arable crops, pasture, forests and urban areas (STATBEL 2020). The small- and mediumsized carnivores we study here are red fox, European badger, stone marten, European polecat, stoat and least weasel. Of these, only red fox could be hunted or killed intentionally during the sampling period in Flanders.

Flanders is a densely populated region with a dense road network; thus, gathering samples by collecting road killed animals is feasible here. In 1997, a network of 123 volunteers and colleagues and a total of 38 collection points was set up covering the whole study area (see VAN DEN BERGE et al. 2021). When anyone encountered a dead small- or medium-sized carnivore, mostly road killed animals, they could report it (Fig. 1). Subsequently, a volunteer from the network went to collect the animal carcasses and took them to a collection point where each specimen was stored at $-20^{\circ} \mathrm{C}$. Carcasses of the six study

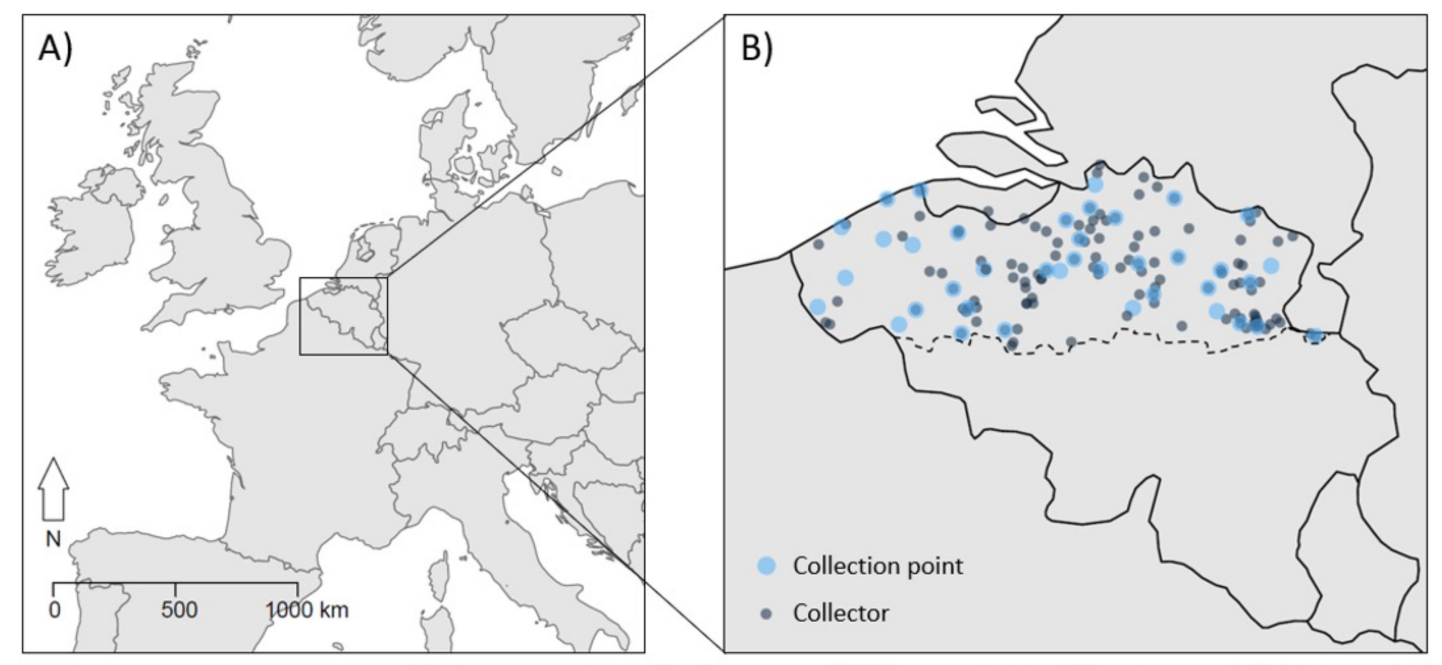

Figure 1 - Overview of the study setup. A. Location of the study area in Europe. B. Location of the different collection points $(n=38)$ and collectors (i.e., residences of the participating volunteers, $n=$ 123) during the sampling from 1998 to 2018 in Flanders, Belgium (B). 
species were collected from 1 January 1998 to 31 December 2018. Each specimen was given a unique ID and the location and date of collection were recorded. Several times a year the collected specimens were centralized at the Research Institute for Forest and Nature (Geraardsbergen, Flanders), where they were again stored at $-20^{\circ} \mathrm{C}$ up to the necropsy. From the necropsy, stomachs were isolated, weighted and refrozen prior to dietary analyses.

\section{Stomach analyses}

Before identification of the stomach contents, stomachs were defrosted and an initial inspection was carried out to identify the presence of liquids or easily soluble food items, such as bird eggs or breadcrumbs. Stomach contents were then rinsed under a light water stream over a sieve (mesh size $0.5 \mathrm{~mm}$ ), after which the solid food items were sorted and identified. The food items were determined macroscopically to the most detailed level possible following reference determination works (READE \& HOSKING 1968; BROWN et al. 1998; TEERINK 1999) and the reference collection of the Forest and Nature Research Institute. When necessary, a binocular microscope was used, e.g., for identification of pieces of eggshells. The following main food types were distinguished:

1. Edible waste

2. Non-edible waste

3. Vegetative bulk material

4. Fruits

5. Grains and nuts

6. Mushrooms

7. Invertebrates (i.e., Annelida spp., Gastropoda spp., Carabidae spp., Geotrupidae spp., Coleoptera spp., Forticula spp., Oniscidae spp., Caelifera spp., Bombus spp. and Vespinae spp., Noctua spp., Bombycoidae spp. and Tipulidae spp.)

8. Amphibians (i.e., Bufo spp. and Rana spp.)

9. Bird eggs (i.e., Columbidae spp., Passeriformes spp., Gallus spp., Phasianus spp. and Perdix spp., Galliformes spp. and Anseriformes spp.)

10. Birds (i.e., Columbidae spp., Passeriformes spp., Gallus spp., Phasianus spp. and Perdix spp., Galliformes spp., Anseriformes spp. and Rallidae spp.)

11. Lagomorphs (i.e., Lepus europaeus and Oryctolagus spp.)

12. Rodents (i.e., Muridae spp., Rattus spp., Microtinae spp., Arvicola spp. and Ondatra spp.)

13. Other mammals (i.e., Erinaceus europaeus and Scoridae spp.)

14. Other or undefined vertebrates

Regarding both the birds and bird eggs, we distinguished pigeons and doves, songbirds, chickens, pheasants and partridges, ducks, rails and undefined birds. Lagomorphs were identified as either hares, rabbits, or undefined hares and rabbits. For the rodents, we distinguished true mice, rats, voles, water voles, muskrats and undefined rodents.

For diet studies, two approaches are commonly used, i.e., the analysis of scats and the analysis of stomachs and intestines. A major advantage of using stomachs is that they allow for a much more accurate recognition and determination of the consumed food types. In addition, an estimation of the original volume per food category is possible including the identification of liquid or easily soluble components. Scat research, on the other hand, has the advantage of integrating different meals in one sample. It is however more difficult to identify the original food types and it is almost impossible to trace back soluble food types. In a region where hunting of almost all small- and medium-sized carnivores is prohibited, such as in Flanders, scats are somewhat easier to collect compared to stomach collection. 
However, compared to scat sampling, with stomach research there can never be any doubt about the species whose diet is being analyzed and all collected stomachs will fully contribute to the sampling.

\section{Data analyses}

Data of the consumed game and pest species were compiled as presence/absence data (p/a). For each game and pest species, the frequency of occurrence (FO, \%) was calculated for each food item as the number of times a certain food item was identified divided by the total number of stomachs per species. For the pheasants and partridges, both the presence of feathers and eggs were considered. The sum of the FO of game species is considered as a proxy for a negative ES, whereas the sum of the FO of pest species represents a positive ES. For the first research questions, we tested whether pest species consumption differed between carnivore species by means of a generalized linear model with carnivore species as fixed factor. For the consumption of game species, the same model was executed. In case of significant differences, a post-hoc analysis was performed to compare pest or game species consumption between two different carnivore species. For our second research question, we tested if each carnivore species consumed more game or pest species by means of generalized linear mixed-effect models. The presence of game or pest species in the stomach in relation to the consumption in every carnivore species was modeled as a binomial random intercept model with a cloglog link function (ZUUR et al. 2009). The categorical variable prey species was modelled as a fixed effect, the specimen ID was used as grouping for the random intercept.

All analyses were performed with R 4.0.3 (R DEVELOPMENT CORE TEAM 2020).

\section{Results}

From 1998 to 2006, a total of 215 badgers and 186 red foxes were collected with intact stomachs containing food remains. Between 1998 and 2013, 776 stone martens and 784 polecats with intact stomachs were collected, and between 1998 and 2018, 62 stoats and 93 weasels with intact stomachs were collected. In total, 4468 food items were identified in the 2116 stomachs of all the predator species collected, accounting for 53 different food subtypes. An overview of the FO\% of the main food types per species and the food subtypes is given in Table S1 and Table S2, respectively. For a more detailed and general description of the study species, their diet breadth, composition and diet overlap we refer to VAN DEN BERGE et al. (2021). For every small- and medium-sized carnivore species, the FO (\%) of each pest and game species is listed in Table 1.

For testing our first hypothesis, we found that both consumption of pest and game species was significantly different among carnivore species $\left(X^{2}=140.2, \mathrm{p}<0.001\right.$ for pest species; for game species $X^{2}=60.6, \mathrm{p}<$ 0.001). Post-hoc comparisons are listed in Table 2 and showed that all other carnivore species consume more pest species compared to badger, fox consumes more pest species compared to stone marten and less compared to weasel, stone marten consumes less pest species compared to polecat and both polecat and stone marten consume less pest species compared to stoat and weasel. Concerning game species, we show that only fox consumes more game species when compared to badger, stone marten and polecat (Table 2).

Regarding our second hypothesis, we found that consumption of pest species was significantly higher than the consumption of game species in red fox (estimate $=0.82, \mathrm{SE}=0.27, \mathrm{p}<0.01$ ), badger (estimate $=$ $5.34, \mathrm{SE}=2.61, \mathrm{p}<0.041)$, stone marten (estimate $=1.87, \mathrm{SE}=0.28, \mathrm{p}<0.001)$ and polecat (estimate $=$ $1.50, \mathrm{SE}=0.19, \mathrm{p}<0.001)$. Stoat and weasel were not modeled as these species did not consume any game species. 


\section{TABLE 1}

Frequency of occurrence (FO, \%) of each pest (rats and voles) and game species (pheasants \& partridges and hares) found in the stomachs of each small- and medium-sized carnivore species. Negative ecosystems service is the sum of pheasants, partridges and hares and positive ecosystem services is the sum of rats and voles.

\begin{tabular}{lcccccc}
\hline & \multicolumn{5}{c}{ Small- and medium-sized carnivore } \\
\cline { 2 - 7 } & Fox & Badger & Stone marten & Polecat & Stoat & Weasel \\
\hline Pheasants \& partridges & 8.4 & 0.5 & 1.9 & 4.1 & 0.0 & 0.0 \\
Hares & 4.2 & 0.5 & 0.5 & 0.9 & 0.0 & 0.0 \\
Rats & 17.2 & 1.1 & 5.7 & 12.8 & 3.2 & 2.2 \\
Voles & 8.4 & 1.6 & 6.3 & 6.3 & 38.7 & 44.1 \\
\hline Negative ecosystem service & 12.6 & 1.0 & 2.4 & 5.0 & 0.0 & 0.0 \\
Positive ecosystem service & 25.6 & 2.7 & 12.0 & 19.1 & 41.9 & 46.3 \\
\hline
\end{tabular}

TABLE 2

Generalized linear model of the effect of species on the consumption of both pest (rats and voles) and game species (pheasants, partridges and hares) (pairwise comparisons). Test statistics are given: estimate, standard error (SE) and adjusted p-value according to Bonferroni correction.

\begin{tabular}{lcccccc}
\hline & \multicolumn{3}{c}{ Pest } & \multicolumn{3}{c}{ Game } \\
\cline { 2 - 7 } & estimate & $\mathbf{S E}$ & $\mathbf{p}$ & estimate & $\mathbf{S E}$ & $\mathbf{p}$ \\
\hline Badger - fox & -2.74 & 0.48 & $<0.001$ & -2.851 & 0.74 & $<0.01$ \\
Badger - stone marten & -1.74 & 0.47 & $<0.01$ & -0.807 & 0.75 & 0.99 \\
Badger - polecat & -2.26 & 0.46 & $<0.001$ & -1.691 & 0.73 & 0.31 \\
Badger - stoat & -3.41 & 0.52 & $<0.001$ & 13.898 & 828.37 & 0.99 \\
Badger - weasel & -3.59 & 0.49 & $<0.001$ & 13.898 & 676.36 & 0.99 \\
Fox - stone marten & 0.99 & 0.20 & $<0.001$ & 2.044 & 0.33 & $<0.001$ \\
Fox - polecat & 0.47 & 0.19 & 0.18 & 1.16 & 0.26 & $<0.01$ \\
Fox - stoat & -0.68 & 0.31 & 0.41 & 16.749 & 828.37 & 0.99 \\
Fox - weasel & -0.85 & 0.27 & 0.02 & 16.749 & 676.36 & 0.99 \\
Stone marten - polecat & -0.52 & 0.14 & $<0.01$ & -0.884 & 0.30 & 0.05 \\
Stone marten - stoat & -1.67 & 0.28 & $<0.001$ & 14.705 & 828.37 & 0.99 \\
Stone marten - weasel & 1.84 & 0.24 & $<0.001$ & -14.705 & 676.36 & 0.99 \\
Polecat - stoat & -1.15 & 0.27 & $<0.01$ & 15.589 & 828.37 & 0.99 \\
Polecat - weasel & -1.32 & 0.23 & $<0.001$ & 15.589 & 676.36 & 0.99 \\
Stoat - weasel & -0.18 & 0.33 & 0.99 & 0 & 109.42 & 0.99 \\
\hline
\end{tabular}




\section{Discussion}

Our study demonstrates that most of the small- and medium-sized carnivores that were included in the study consume game species as well as pest species. Consumption of pest and game species did differ between carnivore species, confirming our first hypothesis. In addition, the consumption of pest species (i.e., positive ES) was clearly higher than the consumption of game species (i.e., negative ES) for all carnivore species in this study, confirming our second hypothesis. We found that badger, stoat and weasel consumed no or very few pheasant and partridges and that badger, polecat, stone marten, stoat and weasel consumed no or very few hares. On the other hand, all small- and medium-sized carnivores were found to consume both rats and voles.

Red fox consumed the highest proportion of both game and pest species in its diet. Indeed, foxes are known to be opportunistic omnivores and regularly include a diverse range of birds, hares and small rodents in their diet (LANSZKI et al. 1999; BARRULL et al. 2014; VAN DEN BERGE et al. 2021). The diet of stoat and weasel in continental Europe is known to be specialized towards small rodents, birds and bird eggs, and to hares and rabbits only to a lesser extent (LANSZKI et al. 1999; ELMEROS 2006; VAN DEN BERGE et al. 2021). Hence, the fact that they consumed no game species over the entire study period is surprising. Badger is often described as a more omnivorous species because its diet mainly consists of fruits, invertebrates, grains and nuts (LANSZKI et al. 1999; BARRULL et al. 2014; VAN DEN BERGE et al. 2021), what can be confirmed here, as this species consumed very little game and pest species. Both stone marten and polecat consumed both game and pest species, but again, for both carnivore species, more pest than game species were consumed, as could be expected (e.g., GOSZCZYŃSKI 1976; LODÉ 1997; LANSZKi et al. 1999; LANSZKi 2003; RYSAVA-Novakova \& KoubeK 2009; VAN Den Berge et al. 2021).

Based on these results we concluded that the predation impact in Flanders on small game species seems to be limited or even non-existing for stoat and weasel, in contradiction to the often-assumed negative ES. Hares together with pheasants and partridges as ground-nesting birds are considered to be extra vulnerable in terms of predation impact on their reproduction and as a consequence on the possible hunting bag size in autumn, especially from mammals (REYNOLDS et al. 2010; Roos et al. 2018). The role of predation is hard to test, because of the paucity of data concerning predation across Europe (MCMAHON et al. 2020). However, in this study, we demonstrated the very limited presence of these game species (or birds' eggs) in the diet of badger, stoat and weasel. Red fox, stone marten and polecat consumed small game species to a certain degree. Therefore, from a hunters' and some other stakeholders' point of view, this result could be used as an argument, together with social-psychological drivers as analysed by SWAN et al. (2020), to manage generalist carnivores like red fox or stone marten through intentional killing. However, for polecat, this is hardly defendable as this species is generally in decline in Europe (BAGHLI \& VERHAGEN 2003; CROOSE et al. 2018) and specifically also in our study area (VAN DEN BERGE et al. 2019). On the other hand, all studied species, although badger to a lesser extent, appear to be important actors in the top-down control of pest rodents. In a region as densely populated as Flanders, the regulatory effects of rodent pest species by natural enemies represent important and valuable positive ES, with a direct effect to an elaborated part of the entire human population.

We conclude that these studied carnivores are at the top of the food web in Flanders where they, with regard to their dietary ecology, fulfil positive ES rather than negative ES in terms of consumption of pest and game species. Future social research could explore how various numbers of stakeholders or residents of Flanders view these species and their apparent impacts with regard to these ES - apart from their intrinsic biodiversity value and other possible ES. 


\section{Acknowledgements}

The authors would like to thank the volunteers who helped to collect the animal samples during 19982018. We also thank our colleague Filip Berlengee for doing a great job by necropsying the collected animals. This operating 'marten network' could rely on the financial support by the Flemish Agency for Nature \& Forests (ANB) and the logistic support by the Royal Belgian Institute of Natural Sciences (KBIN/IRSNB). The authors declare no conflict of interest.

\section{References}

BAghli A. \& Verhagen R. (2003). The distribution and status of the polecat Mustela putorius in Luxembourg. Mammal Review 33: 57-68.

Barrull J., Mate I., Ruiz-Olmo J., Casanovas J.G., Gosàlbez J. \& Salicrú M. (2014). Factors and mechanisms that explain coexistence in a Mediterranean carnivore assemblage: An integrated study based on camera trapping and diet. Mammalian Biology 79: 123-131.

https://doi.org/10.1016/j.mambio.2013.11.004

Bro E., Sarrazin J., Clobert J. \& Reitz F. (2000). Demography and decline of the grey partridge Perdix perdix in France. Journal of Applied Ecology 37: 432-448.

BROWN R., FERGUSON J. \& LAWRENCE M. (1998). Vogelsporen: determineergids voor sporen, veren, braakballen, schedels en andere tekens van Europese vogels. Tirion natuur, Den Haag.

Clout M.N. (2002). Biodiversity loss caused by invasive alien vertebrates. Zeitschrift für Jagdwissenschaften 48: 51-58.

Croose E., Duckworth J., Ruette S., Skumatov D., Kolesnikov V. \& Saveljev A. (2018). A review of the status of the Western polecat Mustela putorius: a neglected and declining species? Mammalia 82: $550-564$.

díaz S., Pascual U., Stenseke M., Martín-López B., Watson R.T., Molnár Z., Hill R., Chan K.M.A., Baste I.A., Brauman K.A., Polasky S., Church A., Lonsdale M., Larigauderie A., Leadley P.W., Van Oudenhoven A.P.E., Van der PlaAt F., Schröter M., Lavorel S., Aumeeruddy-Thomas Y., Bukvareva E., Davies K., Demissew S., Erpul G., FaIller P., Guerra C.A., Hewitt C.L., Keune H., Lindley S. \& Shirayama Y. (2018). Assessing nature's contributions to people. Science 359 (6373): 270-272. https://doi.org/10.1126/science.aap8826

Eeraerts M., Smagghe G. \& Meeus I. (2019). Pollinator diversity, floral resources and semi-natural habitat, instead of honey bees and intensive agriculture, enhance pollination service to sweet cherry. Agriculture, Ecosystems and Environment 284: 106586. https://doi.org/10.1016/j.agee.2019.106586

Elmeros M. (2006). Food habits of stoats Mustela erminea and weasels Mustela nivalis in Denmark. Acta Theriologica 51 (2): 179-186. https://doi.org/10.1007/BF03192669

EwER R.F. (1973). The Carnivores. Weidenfeld and Nicholson, London, 494 p.

GOSZCZYŃSKI J. (1976). Composition of the food of martens. Acta Theriologica 21 (36): 527-534.

HAINES-Young R.H. \& PotSCHIN M. (2013). CICES V4.3 - Revised report prepared following consultation on CICES Version 4, August-December 2012. EEA Framework.

HANSKi I., HentTONEN H., KorPimäKi E., OKSANEN L. \& TURCHIN P. (2001). Small-rodent dynamics and predation. Ecology 82 (6): 1205-1520.

Hoeks S., Huijbregts M.A.J., Busana M., Harfoot M.B.J., Svenning J.C. \& SAntini L. (2020). Mechanistic insights into the role of large carnivores for ecosystem structure and functioning. Ecography 43 (12): 1752-1763. https://doi.org/10.1111/ecog.05191 
VAN DEN BERGE K. et al., Consumption of game and pest species by carnivores

Hofmeester T.R., Jansen P.A., Wijnen H.J., Coipan E.C., Fonville M., Prins H.H.T., Sprong H. \& VAN WIEREN S.E. (2017). Cascading effects of predator activity on tick-borne disease risk. Proceedings of the Royal Society B 284: 20170453. https://doi.org/10.1098/rspb.2017.0453

INBO (2021). Trends in afschotstatistieken en schattingen van de voorjaarspopulatie. Available from https://www.vlaanderen.be/inbo/trends-in-afschotstatistieken-en-schattingen-van-de-voorjaarspopulatie/ [accessed 25 January 2022].

JACOB J., MANSON P., BARFKNECHT R. \& FREDRICKS T. (2014). Common vole (Microtus arvalis) ecology and management: implications for risk assessment of plant protection products. Pest Management Science 70 (6): 869-878. https://doi.org/10.1002/ps.3695

Keune H., Kretsch C., De Blust G., Gilbert M., Flandroy L., Van Den Berge K., Versteirt V., Hartig T., De KeERSMAECKer L. \& EgGermont H. (2013). Science-policy challenges for biodiversity, public health and urbanization: examples from Belgium. Environmental Research Letters 8: 025015. https://doi.org/10.1088/1748-9326/8/2/025015

KuiJPer D.P.J., OOSTERVELD, E. \& WyMENGA E. (2009). Decline and potential recovery of the European grey partridge (Perdix perdix) population - a review. European Journal of Wildlife Research 55: 455463. https://doi.org/10.1007/s10344-009-0311-2

LANSZKI J. (2003). Feeding habits of stone martens in a Hungarian village and its surroundings. Folia Zoologica 52 (4): 367-377.

LANSZKi J. \& HELTAi M. (2007). Diet of the European polecat and the steppe polecat in Hungary. Mammalian Biology 72 (1): 49-53. https://doi.org/10.1016/j.mambio.2006.07.002

LANSZKi J., KÖRMENDi S., HANCZ C. \& ZALEWSKI A. (1999). Feeding habits and trophic niche overlap in a Carnivora community of Hungary. Acta Theriologica 44 (4): 429-442.

https://doi.org/10.4098/AT.arch.99-41

Lichtenberg E.M., Kennedy C.M., Kremen C., BatáRy P., Berendse F., Bommarco R., _BosquePérez N.A., Carvalheiro L.G., Snyder W.E., Williams N.M., Winfree R., Klatt B.K., Åström S., Benjamin F., Brittain C., Chaplin-Kramer R., Clough Y., Danforth B., Diekötter T., Eigenbrode S.D., Ekroos J., Elle E., Freitas B.M., Fukuda Y., Gaines-Day H.R., Grab H., Gratton C., Holzschuh A., Isaacs R., Isaia M., Jha S., Jonason D., Jones V.P., Klein A.M., Krauss J., Letourneau D.K., Macfadyen S., Mallinger R.E., Martin E.A., Martinez E., Memmott J., Morandin L., Neame L., Otieno M., Park M.G., Pfiffner L., Pocock M.J.O., Ponce C., PotTs S.G., Poveda K., Ramos M., Rosenheim J.A., RundlÖF M., SARdiñas H., SAunders M.E., Schon N.L., Sciligo A.R., Sidhu C.S., Steffan-Dewenter I., TscharntKe T., VeselÝ M., WeisSER W.W., Wilson J.K. \& Crowder D. W. (2017). A global synthesis of the effects of diversified farming systems on arthropod diversity within fields and across agricultural landscapes. Global Change Biology 23 (11): 4946-4957. https://doi.org/10.1111/gcb.13714

LODÉ T. (1997). Trophic status and feeding habits of the European polecat Mustela putorius L. 1758. Mammal Review 27: 177-184. https://doi.org/10.1111/j.1365-2907.1997.tb00447.x

Lund M. (2015). Commensal rodents. In: Buckle A.P. \& SMith R.H. (eds) Rodent Pests and their Control, $2^{\text {nd }}$ edition: 19-32. CAB International, Wallingford.

https://doi.org/10.1079/9781845938178.0000

McMahon B.J., Doyle S., Gray A., Kelly S.B.A. \& RedPATH S.M. (2020). European bird declines: do we need to rethink approaches to the management of abundant generalist predators? Journal of Applied Ecology 57 (10): 1885-1890. https://doi.org/10.1111/1365-2664.13695

OSTFELD R.S. \& HOLT R.D. (2004). Are predators good for your health? Evaluating evidence for topdown regulation of zoonotic disease. Frontiers in Ecology and the Environment 2 (1): 13-20. 
Pisman A., Vanacker S., Willems P., Engelen G. \& Poelmans L. (eds). (2018). Ruimterapport Vlaanderen (RURA). Een ruimtelijke analyse van Vlaanderen. Departement Omgeving, Brussel.

PosŁuszny M., Pilot M., GoszczyŃski J. \& GralaK B. (2007). Diet of sympatric pine marten (Martes martes) and stone marten (Martes foina) identified by genotyping of DNA from faeces. Annales Zoologici Fennici 44 (4): 269-284.

Prugh L.R., Stoner C.J., Epps C.W., Bean W.T., Ripple W.J., Laliberte A.S. \& Brashares J.S. (2009). The rise of the mesopredator. BioScience 59 (9): 779-791.https://doi.org/10.1525/bio.2009.59.9.9

READE W. \& Hosking E. (1968). Broedende vogels, hun nesten, eieren en jongen. Moussault, Amsterdam.

R Development Core Team. (2020). R: A Language and Environment for Statistical Computing. R Foundation for Statistical Computing, Vienna, Austria.

REYNOLDS J.C. \& TAPPER S.C. (1996). Control of mammalian predators in game management and conservation. Mammal Review 26: 127-156.

Reynolds J.C, StoAte C., BRockless M.H., AeBischer N.J. \& TAPPER S.C. (2010). The consequences of predator control for brown hares (Lepus europaeus) on UK farmland. European Journal of Wildlife Research 56: 541-549. https://doi.org/10.1007/s10344-009-0355-3

Ritchie E.G., Elmhagen B., Glen A.S., Letnic M., Ludwig G. \& McDonald R.A. (2012). Ecosystem restoration with teeth: what role for predators? Trends in Ecology and Evolution 27 (5): 265-271.

https://doi.org/10.1016/j.tree.2012.01.001

ROBERTSON P.A. \& ROSENBERG A.A. (1988). Harvesting gamebirds. In: HudSON P.J. \& RANDS M.R.W. (eds) Ecology and Management of Gamebirds: 177-201. Blackwell Scientific Publications, London.

Roemer G.W., Gompper M.E. \& VAn ValKenburgh B. (2009). The ecological role of the mammalian mesocarnivore. Bioscience 59: 165-173. https://doi.org/10.1525/bio.2009.59.2.9

Roos S., SMART J., GibBOnS D.W. \& Wilson J.D. (2018). A review of predation as a limiting factor for bird populations in mesopredator-rich landscapes: a case study of the UK. Biological Reviews 93 (4): 1915-1937. https://doi.org/10.1111/brv.12426

Rysava-Novakova M. \& KoubeK P. (2009). Feeding habits of two sympatric mustelid species, European polecat Mustela putorius and stone marten Mattes foina, in the Czech Republic. Folia Zoologica 58 (1): 66-75.

Sainsbury K.A., Shore R.F., Schofield H., Croose E., HantKe G., Kitchener A.C. \& McDonald R.A. (2020). Diets of European polecat Mustela putorius in Great Britain during fifty years of population recovery. Mammal Research 65 (2): 181-190. https://doi.org/10.1007/s13364-020-00484-0

Scheppers T., Verzelen Y., Devos K., Huysentruyt F., Casaer J., Adriaens T., De Bruyn L., Van Den Berge K., VAn DAele T. \& Vermeersch G. (2019). De impact van jacht op patrijzenpopulaties: Wat kunnen populatiemodellen ons leren? Rapporten van het Instituut voor Natuur- en Bosonderzoek 2019 (29). Instituut voor Natuur- en Bosonderzoek, Brussel. https://doi.org/10.21436/inbor.15402520

Schulp C.J.E., Thuiller W. \& VerbuRG P.H. (2014). Wild food in Europe: a synthesis of knowledge and data of terrestrial wild food as an ecosystem service. Ecological Economics 105: 292-305. https://doi.org/10.1016/j.ecolecon.2014.06.018

SILLERO-SUBIRI C. \& LAURENSON K. (2001). Interactions between carnivores and local communities: conflic or co-existence? Carnivore Conservation (January 2001): 282-312.

Sliwinski K., Ronnenberg K., Jung K., Strauss E. \& Siebert U. (2019). Habitat requirements of the European brown hare (Lepus europaeus Pallas 1778) in an intensively used agriculture region (Lower Saxony, Germany). BMC Ecology 19 (1): 1-11. https://doi.org/10.1186/s12898-019-0247-7 
STATBEL (2020). Bodemgebruik in België vanaf 1980.

Available from https://statbel.fgov.be/n1/themas/leefmilieu/grond/bodemgebruik\#figures [accessed 16 November 2020].

Swan G.J.F., Redpath S.M., Crowley S.L. \& McDonald R.A (2020). Understanding diverse approaches to predator management among gamekeepers in England People and Nature 2020 (2): 495-508. https://doi.org/10.1002/pan3.10091

Tambling C.J., Avenant N.L., Drouilly M. \& Melville H. (2018). The role of mesopredators in ecosystems: potential effects of managing their populations on ecosystem processes and biodiversity. In: KERLEY G.I.H., WILSON S.L. \& BALFOUR D. (eds) Livestock Predation and its Management in South Africa: a Scientific Assessment: 205-227. Centre for African Conservation Ecology, Nelson Mandela University, Port Elizabeth.

TAPPER S.C., PotTS G.R. \& BROCKLESS M.H. (1996). The effect of an experimental reduction in predation pressure on the breeding success and population density of grey partridges Perdix perdix. Journal of Applied Ecology 33: 965-978.

TEERINK B.J. (1991). Atlas and Identification Key Hair of West-European Mammals. Cambridge University Press, Cambridge.

VAn Den Berge K., Gouwy J. \& De KniJf G. (2019). Staat van instandhouding (status en trends) van de soorten van de Habitatrichtlijn. Deelrapport niet-vliegende zoogdieren (rapportageperiode 20132018). Rapporten van het Instituut voor Natuur- en Bosonderzoek 2019 (11). Instituut voor Natuur- en Bosonderzoek, Brussel. https://doi.org/10.21436/inbor.16136075

Van Den Berge K., Van Der Veken T., Gouwy J., Verschelde P. \& Eeraerts M. (2021). Dietary composition and overlap among small- and medium-sized carnivores in Flanders, Belgium. Ecological Research 37: 163-170. https://doi.org/10.1111/1440-1703.12276

Zuur A., Ieno E.N., Walker N., Saveliev A.A. \& Smith G.M. (2009). Mixed Effects Models and Extensions in Ecology with R. Springer Science and Business Media.

Manuscript received: 10 June 2021

Manuscript accepted: 22 January 2022

Published on: 3 February 2022

Branch editor: Zjef pereboom 